\title{
In the Blink of an Eye: Relating Positive-Feedback Sensitivity to Striatal Dopamine $\mathrm{D}_{2}$-Like Receptors through Blink Rate
}

\author{
Stephanie M. Groman, ${ }^{1,5,6}$ Alex S. James, ${ }^{1}$ Emanuele Seu, ${ }^{1}$ Steven Tran, ${ }^{1}$ Taylor A. Clark, ${ }^{1}$ Sandra N. Harpster, ${ }^{1}$ \\ Maverick Crawford, ${ }^{1}$ Joanna Lee Burtner, ${ }^{1}$ Karen Feiler, ${ }^{1}$ Robert H. Roth, ${ }^{5,6}$ John D. Elsworth, ${ }^{5,6}$ Edythe D. London, ${ }^{2,3,4}$ \\ and $\mathbb{D}^{-}$James David Jentsch ${ }^{1,2,4}$ \\ Departments of ${ }^{1}$ Psychology, ${ }^{2}$ Psychiatry and Biobehavioral Sciences, and ${ }^{3}$ Molecular and Medical Pharmacology and ${ }^{4}$ Brain Research Institute, University \\ of California, Los Angeles, Los Angeles, California 90095, and Departments of ${ }^{5}$ Psychiatry and ${ }^{6}$ Pharmacology, Yale University School of Medicine, New \\ Haven, Connecticut 06510
}

For $>30$ years, positron emission tomography (PET) has proven to be a powerful approach for measuring aspects of dopaminergic transmission in the living human brain; this technique has revealed important relationships between dopamine $\mathrm{D}_{2}$-like receptors and dimensions of normal behavior, such as human impulsivity, and psychopathology, particularly behavioral addictions. Nevertheless, PET is an indirect estimate that lacks cellular and functional resolution and, in some cases, is not entirely pharmacologically specific. To identify the relationships between PET estimates of $\mathrm{D}_{2}$-like receptor availability and direct in vitro measures of receptor number, affinity, and function, we conducted neuroimaging and behavioral and molecular pharmacological assessments in a group of adult male vervet monkeys. Data gathered from these studies indicate that variation in $\mathrm{D}_{2}$-like receptor PET measurements is related to reversal-learning performance and sensitivity to positive feedback and is associated with in vitro estimates of the density of functional dopamine $\mathrm{D}_{2}$-like receptors. Furthermore, we report that a simple behavioral measure, eyeblink rate, reveals novel and crucial links between neuroimaging assessments and in vitro measures of dopamine $\mathrm{D}_{2}$ receptors.

Key words: biomarker; D2-like receptors; Dopamine; eye blink; inhibitory control; PET

\section{Introduction}

Neuroimaging techniques, particularly positron emission tomography (PET), have revealed abnormalities in the function of the dopamine system in individuals with substance use disorders and/or schizophrenia. Relatively low dopamine $\mathrm{D}_{2}$ and/or $\mathrm{D}_{3}$ $\left(\mathrm{D}_{2}\right.$-like) receptor availability, indexed with PET, has been observed in individuals with different forms of addiction (Volkow et al., 1993; Lee et al., 2009), and experiments in animals have indicated that $\mathrm{D}_{2}$-like receptor dysfunction is, at least in part, a consequence of chronic experience with drugs of abuse (Nader et al., 2006; Groman et al., 2012). Alternatively, animals exhibiting relatively low $\mathrm{D}_{2}$-like receptor availability engage in higher rates of drug self-administration than those with higher $\mathrm{D}_{2}$-like receptor availability (Nader et al., 2006), a finding that may be ex-

Received July 22, 2014; revised Sept. 15, 2014; accepted Sept. 16, 2014.

Author contributions: S.M.G., E.D.L., and J.D.J. designed research; S.M.G., E.S., S.T., T.A.C., S.N.H., M.C., J.L.B., K.F., R.H.R., J.D.E., and J.D.J. performed research; S.M.G., A.S.J., and J.D.J. analyzed data; S.M.G., A.S.J., E.D.L., and J.D.J. wrote the paper.

These experiments were supported by the Consortium for Neuropsychiatric Phenomics at University of California, Los Angeles, which is funded by Public Health Service Grants UL1-DE019580 and RL1-DA024853 (E.D.L.) and RL1MH083270 (J.D.J.). Additional support was derived from National Institutes of Health Grants P20-DA022539 (E.D.L.), F31-DA028812 (S.M.G.), and T32-DA024635 (E.D.L.) and grants from the American Psychological Association and the American Psychological Foundation (S.M.G.). We thank Dr. Katherine Karlsgodt for her assistance in manuscript preparation.

Correspondence should be addressed to J. David Jentsch, University of California, Los Angeles, Department of Psychology, Box 951563, Los Angeles, CA 90095. E-mail: jentsch@psych.ucla.edu.

DOI:10.1523/JNEUROSCI.3037-14.2014

Copyright $\odot 2014$ the authors $\quad 0270-6474 / 14 / 3414443-12 \$ 15.00 / 0$ plained by deficient $\mathrm{D}_{2}$ receptor modulation of neural circuits involved in addiction risk factors, such as poor inhibitory control (Groman et al., 2011; Ghahremani et al., 2012). Because dopamine $\mathrm{D}_{2}$-like receptor function may also influence reward sensitivity (Merritt and Bachtell, 2013) and reinforcement learning (Frank et al., 2007), individual differences in these receptors may affect the initiation of drug-taking behavior and its progression into inflexible patterns of drug use. Therefore, PET-based measures of $\mathrm{D}_{2}$-like receptor availability may be a clinically meaningful biomarker of susceptibility for, and the progression of, addictions (Groman and Jentsch, 2012; Jentsch and Pennington, 2014).

However, the biological significance of PET receptor availability, which indexes the total protein/receptor pool accessible for radiotracer binding, has remained elusive because differences/ changes in receptor availability can reflect otherwise diverse mechanisms that affect this single outcome. For example, $\mathrm{D}_{2}$-like receptor availability is influenced by receptor density, levels of endogenous ligand that compete for the same binding site as the radiotracer, or heterogeneity in pools of synaptic, extrasynaptic, and intracellular receptors that likely have different functional implications for neurotransmission (Guo et al., 2010; Ito et al., 2011). Therefore, the multiple potential influences on receptor availability have limited the interpretation of PET-based measures to clarify molecular abnormalities that occur in psychiatric disorders.

The current study sought to address the underlying biological contributors to individual estimates of receptor availability and 
to determine how these contributors relate to one $\mathrm{D}_{2}$-dependent phenotype that is germane to addictions: inhibitory control. To accomplish this goal, we conducted in vitro and in vivo assessments of dopamine receptors within the same vervet monkeys and compared these measures to the behavioral performance of the same subjects in the reversal-learning task that, in part, measures inhibitory control (Izquierdo and Jentsch, 2012). We found that individual differences in striatal $\mathrm{D}_{2}$-like, but not $\mathrm{D}_{1}$-like, receptor availability measured with PET related to the function of $\mathrm{D}_{2}$-like receptors, determined by measuring spontaneous and dopamine agonist-induced eyeblink rate (EBR; Lowry et al., 1951 ), and $D_{2}$-like receptor density assessed in postmortem homogenates. Furthermore, $\mathrm{D}_{2}$-like, but not $\mathrm{D}_{1}$-like, receptor availability related to the performance of monkeys in the reversal phase of a reversal-learning task and to positive-feedback sensitivity. These data provide a rigorous evaluation of factors that underlie individual differences in $\mathrm{D}_{2}$-like receptor availability and suggest that EBR may be a biomarker for $\mathrm{D}_{2}$-like receptor density.

\section{Materials and Methods}

Animal subjects. Vervet monkeys were maintained in accordance with the National Institutes of Health Guide for the Care and Use of Laboratory Animals of the Institute of Laboratory Animal Resources (National Research Council, Department of Health, Education and Welfare Publication 85-23, revised 1996). All experiments conducted were approved by the Chancellor's Animal Research Committee at the University of California, Los Angeles.

Ten adult, male vervet monkeys were included in these studies. All of the subjects were born in the same year (2002) at the Vervet Research Colony, which was then located in Los Angeles, California. The subjects had been removed from their natal groups at adolescence and housed together in peer groups. The subjects were relocated to University of California, Los Angeles in 2008. The monkeys were 5 years old when these experiments began. They had never been the subjects of any pharmacological perturbation studies, only having received semiannual sedation with ketamine (with or without xylazine) as was required for routine veterinary care.

The subjects were pair housed in large, outdoor enclosures $(11 \times 11 \times$ $11 \mathrm{~m}$ ) equipped with various forms of enrichment (swings, barrels, and toys). They received feedings, twice daily, of chow (Teklad), supplemented daily with fresh fruit or vegetables. The monkeys were never food restricted to motivate task performance; however, overnight fasts were imposed before imaging sessions or other circumstances requiring sedation or anesthesia.

Drugs. The dopamine $\mathrm{D}_{2}$-like receptor agonist (+)-4-propyl-9hydroxynaphthoxazine (PHNO) was purchased from Advanced Biochemical Compounds, and the dopamine $\mathrm{D}_{1}$-like receptor agonist (-)-(1 R,3S)-3-adamantyl-1-(aminomethyl)-3,4-dihydro-5,6-dihydroxy$1 \mathrm{H}$-2-benzopyran hydrochloride hydrate (A77636) was purchased from Sigma-Aldrich. Drugs were dissolved in sterile $0.9 \%$ sodium chloride and diluted from stock concentrations using sterile saline on drug-testing days.

Discrimination acquisition, retention, and reversal learning. Monkeys were trained to acquire, retain, and reverse three-choice, novel visual discriminations, using procedures described previously (Groman et al., 2012). On behavioral-testing days, monkeys were moved from their social enclosure into a metal enclosure where a Wisconsin general testing apparatus (WGTA) was mounted. The WGTA was equipped with an operable black screen that separated the monkey from three equally spaced, opaque boxes that were equipped with a hinged opaque lid in which small food rewards (piece of apple, banana, grape, or orange) could be concealed. The lid of each box could be fitted with a unique visual stimulus (clip art from the Microsoft Office library) that the monkeys could view when sitting in the metal enclosure.

Monkeys were trained to open the lid of the boxes to retrieve rewards. Once monkeys were reliably retrieving rewards, novel visual stimuli were placed on the lids of the boxes. Testing session began when the black screen was raised to present the three boxes to the monkey. Monkeys made one response (opening the lid of the box) per trial. A trial was terminated when the monkey made a correct choice, an incorrect choice, or an omission (no response for $2 \mathrm{~min}$ ), and a $20 \mathrm{~s}$ intertrial interval followed. The next trial began with a change in the spatial position of the boxes until either monkeys met a performance criterion (described below) or 30 trials were completed, whichever occurred first.

The first session of a discrimination problem was a discriminationacquisition phase in which monkeys were presented with three novel visual stimuli and required to learn which one of the three stimuli was associated with reward, solely through feedback provided by the task. Once a performance criterion was met (eight correct choices within 10 consecutive trials), the session was terminated and the monkey was returned to his social enclosure. If the performance criterion was not met, the session ended but the same discrimination problem was presented the following day(s) until the performance criterion was met.

One day after reaching criterion in the acquisition phase, monkeys were tested in the retention phase in which the stimulus-reward contingencies remained unchanged from those of the acquisition phase. Immediately after reaching the performance criterion in the retention phase (four correct choices in five consecutive trials), the reversal phase began, with no explicit signal to the monkey. During the reversal phase, the stimulus that was previously rewarded was no longer rewarded, and one of the two previously non-rewarded stimuli was rewarded. The reversal phase continued until the monkey met the performance criterion (eight correct responses in 10 consecutive trials) or until 30 trials had been completed, whichever occurred first. If the performance criterion was not met, the session ended but the same discrimination problem was presented the following day(s) until the performance criterion was met. The number of trials required to reach criterion was the primary dependent measure. Choice behavior of monkeys was also recorded to quantify the types of errors monkeys made and to quantify the sensitivity of each monkey to positive and negative feedback.

Monkeys completed seven acquisition-only sessions before being tested on five acquisition, retention, and reversal discrimination problems. Behavior was assessed in the last two discrimination problems using an enhanced performance criterion (acquisition phase: 18 correct choices in 20 completed trials; retention phase: 9 correct choices in 10 completed trials; reversal phase: 18 correct choices in 20 completed trials). Comparisons between dopamine receptor availability and behavioral performance of subjects involved only the final discrimination problem, because this behavioral assessment was conducted closest in time to the PET scans ( $<2$ months). One subject did not complete the last discrimination problem because of an injury and was excluded from the analysis. The primary dependent measures were the number of trials required to reach criterion in the acquisition, retention, and reversal phases. We also collected the choice behavior of monkeys to quantify the types of errors monkeys made and the sensitivity of each monkey to positive and negative feedback (see below).

Quantifying feedback sensitivity. Learning performance can be influenced by the subject's sensitivity to positive and/or negative outcomes. To quantify feedback sensitivity during the reversal phase, we examined choice behavior of monkeys on a trial-by-trial basis using procedures described previously (Groman et al., 2011). For trials in which a monkey made a correct response and received positive feedback, we calculated the probability that the monkey would (1) effectively use that feedback and persist with the same correct response, (2) ineffectively use the positive outcome and shift responding to the previously reinforced stimulus (perseverative error), or (3) fail to incorporate the positive outcome into behavior and instead shift responding to the never reinforced stimulus (neutral error). For trials in which the monkey made an incorrect response and received negative feedback, we calculated the probability that the subject would (1) effectively use that negative outcome and shift responding to any of the other two stimuli or (2) ineffectively use that negative outcome and persist with the same incorrect response.

PET scans quantifying $D_{1}$ - and $D_{2}$-like receptor availability. PET scans were performed using carbon-11-(8-chloro-5-(7-benzofuranyl)-7hydroxy-3-methyl-2,3,4,5-tetrahydro-1H-3-benzazepine) ([ $\left.{ }^{11} \mathrm{C}\right] \mathrm{NNC}$ - 
112) and $\left[{ }^{18} \mathrm{~F}\right]$ fallypride as radioligands for measurements of $\mathrm{D}_{1^{-}}$and $\mathrm{D}_{2}$-like receptor availability, respectively, using a microPET model $\mathrm{P} 4$ scanner (Concorde Microsystems), which has a fixed width at half maximum (FWHM) spatial resolution of $1.75 \mathrm{~mm}$. PET scans were acquired $<2$ months from the final reversal-learning test reported here. On PET scanning days, monkeys received an intramuscular injection of ketamine hydrochloride $(10 \mathrm{mg} / \mathrm{kg})$ and glycopyrolate $(0.01 \mathrm{mg} / \mathrm{kg})$. After monkeys were sedated, an endotracheal tube was placed to provide $2-3 \%$ isoflurane anesthesia (in $100 \% \mathrm{O}_{2}$ ) for the duration of the procedure. Vital signs (heart rate, respiratory rate, oxygen saturation, and temperature) were monitored and recorded every $15 \mathrm{~min}$ throughout the scan. A tail-vein catheter was placed, and the monkey was positioned on the scanning bed such that the imaging planes were parallel to the orbitomeatel line and the top of the head at the front of the field of view. A $20 \mathrm{~min}{ }^{57} \mathrm{Co}$ transmission scan was acquired before administration of the radioligand for attenuation correction. All subjects received a bolus injection of $\left[{ }^{11} \mathrm{C}\right] \mathrm{NNC}-112(0.3 \mathrm{mCi} / \mathrm{kg})$, followed by a $5 \mathrm{ml}$ saline flush, and data were acquired for $120 \mathrm{~min}$. When radioactivity had fallen to baseline levels $\left(\sim 3 \mathrm{~h}\right.$ after administration of $\left.\left[{ }^{11} \mathrm{C}\right] \mathrm{NNC}-112\right)$, a bolus injection of $\left[{ }^{18} \mathrm{~F}\right]$ fallypride was delivered $(0.3 \mathrm{mCi} / \mathrm{kg})$, followed by a 5 $\mathrm{ml}$ saline flush, and data were acquired for $180 \mathrm{~min}$. After completion of the second PET scan, gas anesthesia was removed, and the monkey was allowed to recover overnight before being returned to his social enclosure. Because of radioligand synthesis problems, 4 of 10 monkeys were scanned in two separate sessions (each involving one of the radioligands), with an interscan period of $30-60 \mathrm{~d}$.

PET data processing. Three-dimensional sinograms were created by binning the $\left[{ }^{18} \mathrm{~F}\right]$ fallypride data into 33 frames (six $30 \mathrm{~s}$ frames, seven $60 \mathrm{~s}$ frames, five $120 \mathrm{~s}$ frames, four $300 \mathrm{~s}$ frames, nine $600 \mathrm{~s}$ frames, one $1200 \mathrm{~s}$ frame, and one $1800 \mathrm{~s}$ frame) and the $\left[{ }^{11} \mathrm{C}\right] \mathrm{NNC}-112$ data into 21 frames (four $60 \mathrm{~s}$ frames, three $120 \mathrm{~s}$ frames, six $300 \mathrm{~s}$ frames, and eight $600 \mathrm{~s}$ frames). We applied a previously validated algorithm to the list-mode data from the transmission scan to generate attenuation maps (Vandervoort and Sossi, 2008). After construction of the attenuation maps, emission list-mode files were reconstructed using Fourier rebinning and filtered backprojection, corrected for normalization, dead time, scatter, and attenuation with software provided by Concorde Microsystems (microPET manager version 2.4.1.1; Siemens). The resultant images had voxel dimensions of $0.949 \times 0.949 \times 1.212 \mathrm{~mm}^{3}$ and matrix dimensions of $128 \times 128 \times 63$. Using FSL (for FMRIB Software Library) View [FMRIB (for Functional Magnetic Resonance (MR) Imaging of the Brain) Software Library version 4], the following ROIs were drawn on the structural MR image of each subject (see MRI methods) by a single experimenter: the caudate nucleus, putamen, ventral striatum, and cerebellum. Reconstructed PET images were corrected for motion and were coregistered to the subject's MR image using the PFUS module within PMOD (version 3.15; PMOD Technologies). Using the putamen and cerebellum ROIs, activity was extracted from the coregistered PET images and imported into the kinetic analysis program within PMOD (PKIN). The time-activity curves were fit using the simple reference tissue model (SRTM) to provide an estimate of the $k 2^{\prime}$ value. Parametric binding maps, showing binding potential $\left(\mathrm{BP}_{\mathrm{ND}}\right)$, were generated for each subject in PXMOD using the SRTM2 model with the fixed $k 2^{\prime}$ value obtained from analysis of the time-activity curves. Activity extracted from the putamen and cerebellum was entered as references for high and low activity areas, respectively. To conduct the voxelwise statistical analysis, each subject's MR image was aligned to a study-specific vervet monkey MR image template using FSL FLIRT (for FMRIB Linear Image Restoration Tool) and the resultant transformation matrix applied to the $\mathrm{BP}_{\mathrm{ND}}$ maps. A $2 \mathrm{~mm}$ FWHM Gaussian smoothing kernel was applied to the binding potential maps.

Magnetic resonance images. MR images for the subjects were collected as a part of a larger study (Fears et al., 2009). Nine T1-weighted volumes with three-dimensional MPRAGE images (TR, $1900 \mathrm{~ms}$; TE, $4.38 \mathrm{~ms}$; field-of-view $96 \mathrm{~mm}$; flip angle, $15^{\circ}$; voxel size, $0.5 \mathrm{~mm}$; 248 slices; slice thickness $0.5 \mathrm{~mm}$ ) were collected using an eight-channel, highresolution knee-array coil (Invivo) in a $1.5 \mathrm{~T}$ Siemens scanner. Individual images were aligned to each other using Statistical Parametric Mapping 5 (Institute of Neurology, University College London, London, UK), aver- aged together, and resliced according to a previously developed MR template (Groman et al., 2013a).

EBR assessments. Most available $\mathrm{D}_{2}$-like receptor radioligands are highly lipophilic (Schmidt et al., 1994; Mukherjee et al., 1995); therefore, differences in receptor availability measurements at least partially reflect intracellular pools of receptors that are unavailable for activation by dopamine and/or are uncoupled from their effector systems. We hypothesized that, if the measured receptor pool includes mostly functional/ coupled receptors, individual differences in PET-based measures of binding potential should directly predict individual differences in dopamine-mediated behaviors, such as eyeblink, that depend on the striatum (Elsworth et al., 1991; Kleven and Koek, 1996; Taylor et al., 1999) and that individual differences in receptor binding potential should predict the magnitude of agonist-induced changes in these behaviors. Spontaneous and drug-induced changes in EBR were assessed from 60-90 min video recordings of the monkeys. These videos were acquired using two high-definition digital video cameras (Sony Bloggie), while monkeys sat otherwise undisturbed in a viewing chamber. The cameras, positioned $90^{\circ}$ from one another, allowed $180^{\circ}$ visibility of the monkey's eyes. These video recordings were then manually scored by experimentally blind raters using a program, developed by a member of our team (A.S.J.), that allowed raters to timestamp the occurrence of a blink (defined as a full opposition of the eyelid that lasted $<1 \mathrm{~s}$ ) and the visibility of the subject's eyes while the rater simultaneously viewed two video streams from the cameras positioned at $90^{\circ}$ from one and other. Video raters were trained to an inter-rater reliability of at least $90 \%$ before beginning analysis of the videos in this study. Data was binned into $5 \mathrm{~min}$ blocks, and the EBR within each block was computed as the total number of blinks per total visibility time. If visibility of the monkey was $<2 \mathrm{~min}$ of the 5 min block, data from that block were excluded from the analysis. Spontaneous EBR was assessed in multiple recording sessions when the monkey was unperturbed and was recorded for $60 \mathrm{~min}$. For the withinsubject dopamine agonist experiments, the EBR was recorded for $30 \mathrm{~min}$ before (baseline) the monkey received an intramuscular injection of either the $\mathrm{D}_{1}$-like receptor agonist (A77636 in $0.9 \% \mathrm{NaCl} ; 0.005,0.05$, or $0.5 \mathrm{mg} / \mathrm{kg}$ ), the $\mathrm{D}_{2}$-like receptor agonist (PHNO in $0.9 \% \mathrm{NaCl} ; 0.005$, 0.05 , or $0.5 \mathrm{mg} / \mathrm{kg}$ ), or saline. EBR was recorded for $60 \mathrm{~min}$ after drug administration. Inspection of the data revealed temporal changes in the EBR after administration of drug that may not have been captured with eyeblink measurements averaged over the entire 60 min session (Fig. 1). EBR increases rapidly after administration of dopamine agonists (Elsworth et al., 1991; Kleven and Koek, 1996), returning to baseline levels 30-40 min after drug administration. To characterize drug-induced changes in EBR fully, we determined the maximal and minimal EBR before and after drug (or vehicle) administration, as well as the average response across the entire session. Drug-induced changes in EBR were determined by subtracting the maximal change in EBR from the maximal baseline EBR recorded within that same session. To verify that the pharmacological effects were drug specific, the change in EBR from baseline after administration of saline was subtracted from the change in EBR from baseline after administration of drug.

Drug sessions were limited to once per week, with the order of dopamine agonist administration pseudorandomly counterbalanced (alternating weekly between doses of the $\mathrm{D}_{1}$-like or $\mathrm{D}_{2}$-like agonist) to avoid receptor sensitization, which reportedly occurs after extended exposure to dopamine receptor agonists (Szumlinski et al., 1997). The maximal change in EBR after administration of saline was assessed before, twice during, and immediately after the drug study and did not significantly change over the period of the drug studies $\left(F_{(3,24)}=0.45 ; p=0.72\right)$, suggesting that multiple exposures to dopamine agonists did not significantly alter spontaneous EBR. Some drug sessions had to be repeated ( $\sim 3$ months after the initial drug sessions) because of cases of poor visibility of an individual monkey's eyes.

Ex vivo assays of monoamine levels and dopamine receptors. Brain tissue was collected from deeply anesthetized monkeys (ketamine hydrochloride, $10 \mathrm{mg} / \mathrm{kg}$, i.m.; sodium pentobarbital, $30 \mathrm{mg} / \mathrm{kg}$, i.v.) after transcardial perfusion with ice-cold saline; samples were stored at $-80^{\circ} \mathrm{C}$ until processed. Monoamine levels were determined using HPLC, as described previously (Jentsch et al., 1997). Radioligand binding assays using 

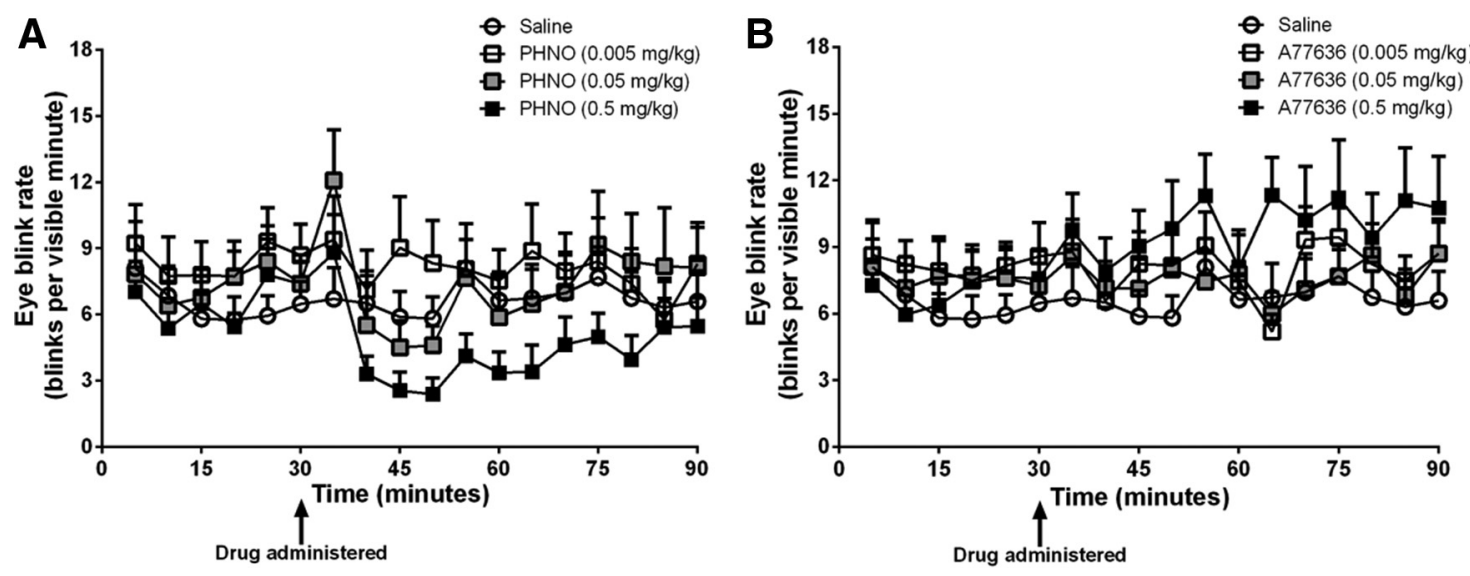

Figure 1. Time course of the average EBR ( \pm SEM) before (first $30 \mathrm{~min}$ ) and after $(60 \mathrm{~min})$ administration of the $\mathrm{D}_{2}$-like receptor agonist PHNO $(\boldsymbol{A})$ or the $\mathrm{D}_{1}$-like receptor agonist A77636 $(\boldsymbol{B})$ at $0.005 \mathrm{mg} / \mathrm{kg}$ (white squares), $0.05 \mathrm{mg} / \mathrm{kg}$ (gray squares), $0.5 \mathrm{mg} / \mathrm{kg}$ (black squares), or vehicle (saline; white circles) in $5 \mathrm{~min}$ bins.

$\left[{ }^{3} \mathrm{H}\right]$ raclopride (PerkinElmer Life and Analytical Sciences) were completed using a published protocol (Levant, 2007). Tissue collected from the putamen, the largest striatal region needed to complete a nine-point saturation curve, was homogenized in buffer [in mм: 50 Tris $\mathrm{HCl}, 50$ Tris base, $5 \mathrm{KCl}, 2 \mathrm{CaCl}_{2}, 2 \mathrm{MgCl}_{2}$, and $120 \mathrm{NaCl}, \mathrm{pH}$ to 7.4 (at $23^{\circ} \mathrm{C}$ )] to achieve a tissue homogenate concentration of $6.5 \mathrm{mg} / \mathrm{ml}$ original wet tissue weight. The homogenates were incubated $(60 \mathrm{~min}$ at room temperature) with nine different concentrations of $\left[{ }^{3} \mathrm{H}\right]$ raclopride $(0-6 \mathrm{nM})$ in the presence or absence of $(+)$ butaclamol $(5 \mu \mathrm{M})$. The reaction was terminated by rapid filtration of samples through GF/B filter paper (presoaked for $1 \mathrm{~h}$ in $0.05 \%$ polyethylenimine at room temperature) using a Brandel cell harvester, followed by three rinses with ice-cold buffer ( 3 $\mathrm{ml} / \mathrm{sample}$ per rinse). Filter paper was dried overnight and incubated in scintillation fluid (Ultima Gold; $5 \mathrm{ml} /$ filter) for $24 \mathrm{~h}$ before being read on a liquid scintillation counter (Beckman LS6500; Beckman Instruments). Protein content of tissue homogenates was determined using the BCA protein assay (Pierce Thermo Scientific). Specific binding was calculated by subtracting nonspecific binding [in the presence of $(+)$ butaclamol] from total binding and normalized to protein content (Lowry et al., 1951). Nine-point saturation curves were generated for each subject. The density of $\left[{ }^{3} \mathrm{H}\right]$ raclopride binding sites $\left(B_{\max }\right)$ and the equilibrium dissociation constant $\left(K_{\mathrm{D}}\right)$ were calculated using the one-site binding function in Prism (version 6; GraphPad Software). Tissue from two subjects was excluded because of high nonspecific binding.

Statistical analyses. Statistical analyses were conducted in SPSS (version 20; IBM). Relationships between variables were assessed either by conducting bivariate correlation analyses or in multivariate regression analyses in which multiple independent variables were regressed against a single dependent variable. Mediation analyses were completed according to Baron and Kenny (1986) using multiple regression analyses. Path analyses were conducted using multiple regressions (Edwards and Lambert, 2007), in which the variance explained by theoretical models, which included variables with different direct and indirect effects, was compared with the variance explained by a fully saturated model (in which all direct and indirect effects are included).

\section{Results}

Relationship between dopamine $D_{1}$-like and $D_{2}$-like receptor availability in the striatum

We first examined the individual-level statistical relationships between $D_{1}$-like and $D_{2}$-like receptor availability in each of three striatal regions of interest. There was a positive relationship between measures of $D_{1}$-like and $D_{2}$-like receptor availability in the putamen $(r=0.63 ; p=0.04)$, but these relationships were not statistically significant for either the caudate nucleus $(r=0.49$; $p=0.15)$ or ventral striatum $(r=0.26 ; p=0.47$; Fig. 2$)$.

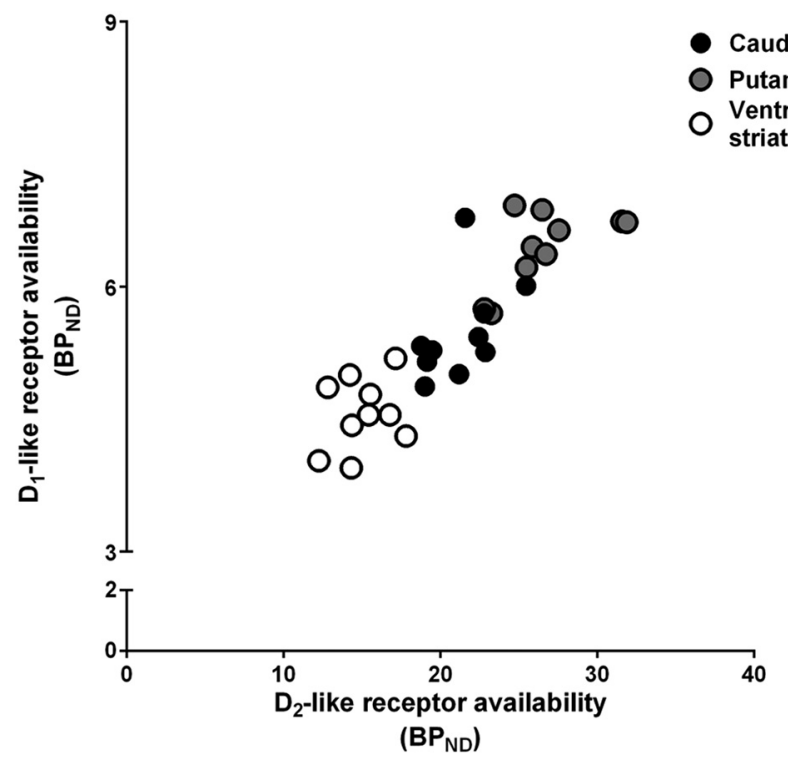

Figure 2. A graphical comparison of the relationship between $\mathrm{D}_{2}$-like and $\mathrm{D}_{1}$-like receptor availability ( $\left.\mathrm{BP}_{\mathrm{ND}}\right)$ in the caudate (black circles), the putamen (gray circles), and the ventral striatum (white circles) for 10 vervet monkeys.

Dopamine $\mathrm{D}_{2}$-like, but not $\mathrm{D}_{1}$-like, receptor availability covaries with reversal-learning performance

We have demonstrated previously that naturally occurring, individual differences in PET-based measures of dopamine $\mathrm{D}_{2}$-like receptor availability covary with reversal-learning performance, a measure of inhibitory control (Groman et al., 2011). Whether a similar relationship exists for individual differences in dopamine $D_{1}$-like receptors has not been reported. $D_{1}$ - and $D_{2}$-like receptor availability were regressed onto indices of behavioral performance of monkeys in the reversal-learning paradigm (Groman et al., 2011). We found that dopamine $\mathrm{D}_{2}$-like, but not $\mathrm{D}_{1}$-like (Fig. $3 B)$, receptor availability in the ventral striatum was correlated with the number of trials required to reach criterion in the reversal phase $(r=0.67 ; p=0.04$; Fig. $3 A)$ but not with performance during initial discrimination acquisition $(r=0.11 ; p=0.77)$ or retention $(r=-0.39 ; p=0.35)$ phases. Monkeys with relatively low dopamine $\mathrm{D}_{2}$-like receptor availability required more trials to reach criterion than those with relatively high dopamine $\mathrm{D}_{2}$ like receptor availability. We then examined whether $\mathrm{D}_{2}$-like receptor availability in the ventral striatum was related to specific 

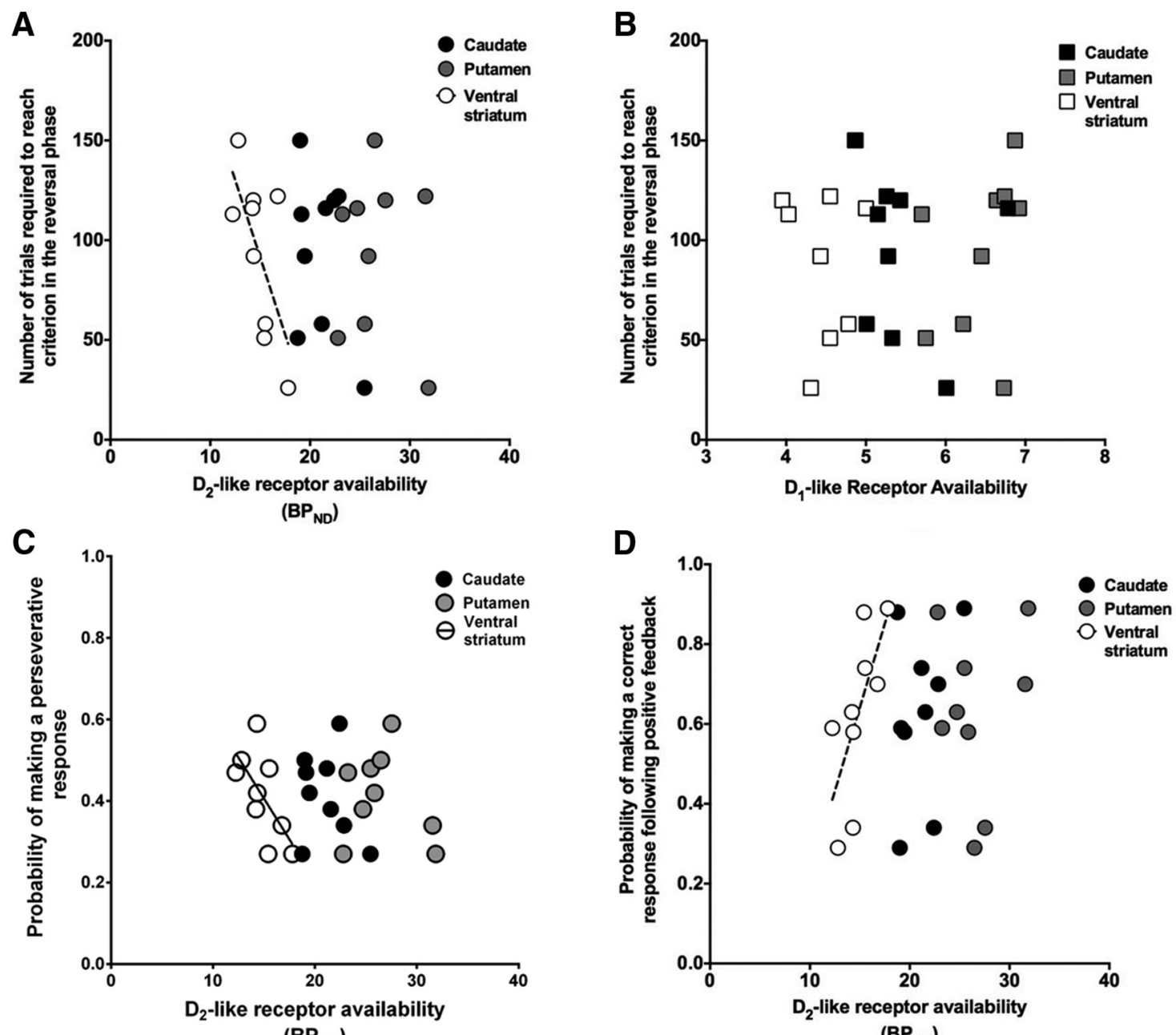

$\left(\mathrm{BP}_{\mathrm{ND}}\right)$

$\left(\mathrm{BP}_{\mathrm{ND}}\right)$

E

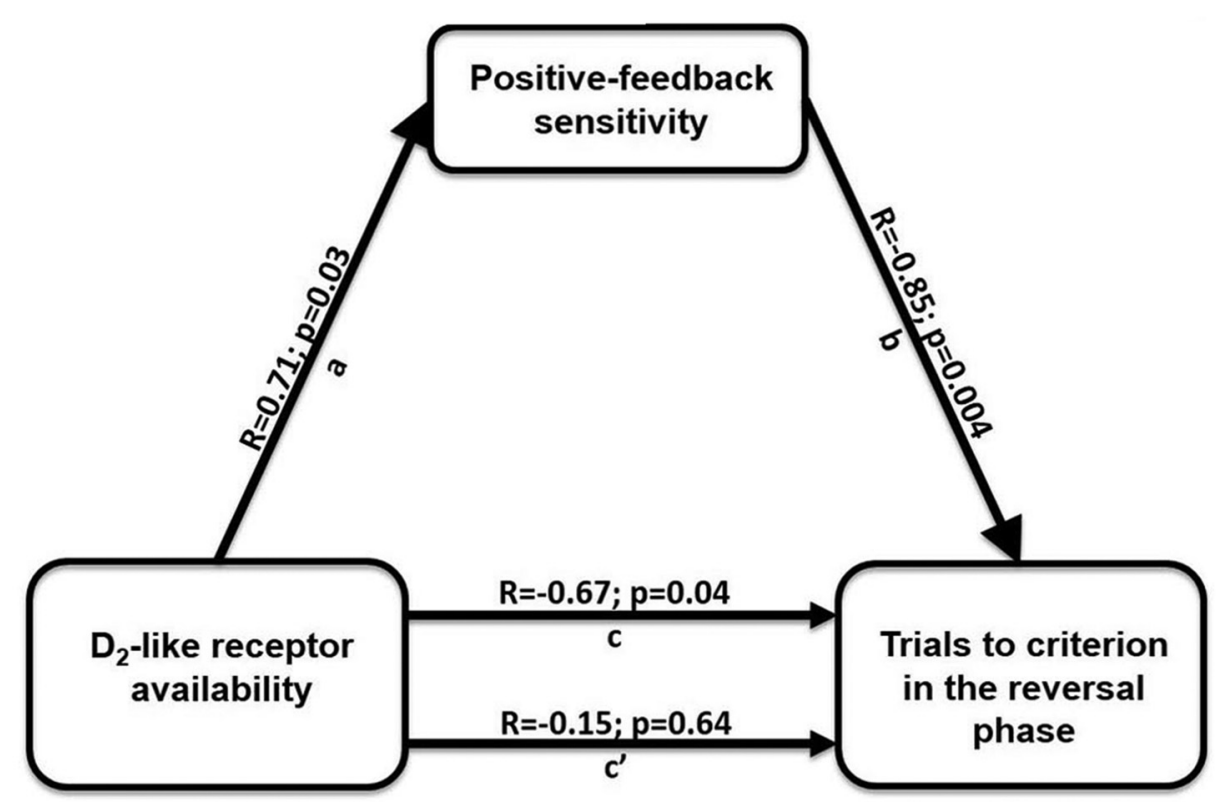

Figure 3. PET $D_{2}$-like receptor availability measurements, but not $D_{1}$-like receptor availability, influence inhibitory control processes by affecting positive-feedback sensitivity. $\boldsymbol{A}$, PET $\mathrm{D}_{2}$-like receptor availability $\left(\mathrm{BP}_{\mathrm{ND}}\right)$ in the ventral striatum (white circles), but not in the caudate nucleus (black circles) or putamen (gray circles), was negatively related to the number of trials required to reach criterion in the reversal phase of the reversal-learning paradigm such that monkeys with higher $\mathrm{D}_{2}$-like receptor availability required fewer trials to reach the performance criterion in the reversal phase. $B, P E T D_{1}$-like receptor availability $\left(\mathrm{BP}_{\mathrm{ND}}\right.$ ) in the ventral striatum (white squares), caudate nucleus (black squares), or putamen (gray squares) was not related to performance in the reversal phase. $C, \mathrm{PET}_{2}$-like receptor availability $\left(\mathrm{BP}_{\mathrm{ND}}\right)$ in the ventral striatum (white circles), but not in the caudate nucleus (black circles) or putamen (gray circles), was negatively related to the probability of making a perseverative response. $D$, PET $\mathrm{D}_{2}$-like receptor availability ( $\mathrm{BP}_{\mathrm{ND}}$ ) in the ventral striatum (white circles), but not in the caudate nucleus (black circles) (Figure legend continues.) 
patterns of responding during reversal-learning phase. $\mathrm{D}_{2}$-like receptor availability was positively related to the probability of making a correct response $(r=0.69 ; p=0.03)$ and negatively related to the probability of making a perseverative response $(r=$ $-0.65 ; p=0.05$; Fig. $3 C$ ) but was not significantly related to the probability of making a response to a stimulus that had never been associated with reward $(r=-0.57 ; p=0.11)$, suggesting that it is the difficulty with inhibiting the initially trained response that is linked with individual estimates of $\mathrm{D}_{2}$-like receptor availability.

A variety of theoretical accounts suggest that striatal dopamine $\mathrm{D}_{1^{-}}$and $\mathrm{D}_{2}$-like receptors may play dissociable roles in behavioral adaptations to positive and negative feedback (Frank et al., 2004; Groman et al., 2011). During reversal learning, $\mathrm{D}_{2}$ like receptor availability in the ventral striatum was positively correlated with the probability of persisting with the same response after positive feedback $(r=0.70 ; p=0.03$; Fig. $3 D)$ and negatively correlated with the probability of making a perseverative response after positive feedback $(r=-0.69 ; p=0.04)$. Conversely, it was not significantly related to the probability of making a response to the never-rewarded stimulus after positive feedback $(r=-0.57 ; p=0.11)$ or the probability of shifting responding after negative feedback $(r=0.19 ; p=0.62) . \mathrm{D}_{1}$-like receptor availability in the ventral striatum was not correlated with sensitivity to either positive $(r=0.09 ; p=0.82)$ or negative $(r=-0.53 ; p=0.14)$ feedback.

To further explore the relationship between $\mathrm{D}_{2}$-like receptor availability and inhibitory control and the directional relationship between these variables, a mediation analysis of the relationships between $\mathrm{D}_{2}$-like receptor availability, positive-feedback sensitivity, and reversal-learning performance was conducted using multiple regressions (Baron and Kenny, 1986). The strong, negative relationship between $\mathrm{D}_{2}$-like receptor availability and performance of monkeys in the reversal phase $(r=-0.67 ; p=$ $0.04)$ was significantly attenuated when positive-feedback sensitivity was included in the model $(r=-0.15 ; p=0.64)$, indicating that the relationship between $D_{2}$-like receptor availability and reversal-learning performance was mediated by influences on positive-feedback sensitivity (Fig. $3 E$ ).

\section{EBR reveals individual differences in $D_{2}$-like, but not $D_{1}$-like, receptor availability}

We quantified EBR in this cohort of monkeys and found that baseline EBR was a highly reliable measurement within and across assessments collected 3 months apart (within-session reliability, Cronbach's $\alpha>0.87$; between-session correlation, $r=$ $0.81, p=0.005)$, suggesting trait-like stability. Notably, baseline EBR was positively related to striatal $\mathrm{D}_{2}$-like receptor availability (ventral striatum, $r=0.74, p=0.01$; caudate nucleus, $r=0.65$, $p=0.04$; putamen, $r=0.58, p=0.07$; Fig. $4 A$ ) but not to $\mathrm{D}_{1}$-like receptor availability (ventral striatum, $r=0.08, p=0.83$; caudate

\footnotetext{
(Figure legend continued.) or putamen (gray circles), was positively related to the probability that monkeys would persist with the same correct response after a positive outcome (positivefeedback sensitivity). $\boldsymbol{E}$, A causal mediation analysis of $\mathrm{D}_{2}$-like receptor availability, positivefeedback sensitivity, and performance in the reversal phase. $\mathrm{D}_{2}$-like receptor availability is positively related to positive-feedback sensitivity (path a) and negatively to reversal-learning performance (path c), whereas positive-feedback sensitivity is negatively related to reversallearning performance (path $\mathrm{b}$ ). When positive-feedback sensitivity is included as a mediator of the relationship between $D_{2}$-like receptor availability and reversal-learning performance, the strength of this relationship was significantly reduced (path $c^{\prime}$ ), indicating that positivefeedback sensitivity mediates the relationship between $D_{2}$-like receptors and reversal-learning performance.
}

$\leftarrow$ nucleus, $r=0.36, p=0.31$; putamen, $r=0.04, p=0.91$; Fig. $4 B$ ). A voxelwise regression analysis confirmed that there was a positive relationship between EBR and $\mathrm{D}_{2}$-like receptor availability throughout the striatum (Fig. 4C,D); no significant clusters were detected when EBR was regressed onto striatal $\mathrm{D}_{1}$-like receptor availability.

Next, we compared $\mathrm{D}_{1}$-like and $\mathrm{D}_{2}$-like receptor availability to changes in $\mathrm{D}_{1}$ agonist and $\mathrm{D}_{2}$ agonist-induced changes in EBR. Average EBR before and after drug (or vehicle) administration is presented in Figure 1. The change in EBR elicited by a low dose of the $\mathrm{D}_{2}$-like receptor agonist (PHNO; $0.005 \mathrm{mg} / \mathrm{kg}$ ) was positively related to striatal $\mathrm{D}_{2}$-like receptor availability in the caudate nucleus $(r=0.64 ; p=0.04)$ and ventral striatum $(r=0.91 ; p<$ $0.001)$, with a similar trend in the putamen $(r=0.61 ; p=0.06$; Fig. $4 E)$. Similar relationships were observed for the medium dose $(0.05 \mathrm{mg} / \mathrm{kg}$; caudate nucleus, $r=0.65, p=0.04$; putamen, $r=0.55, p=0.09$; ventral striatum, $r=0.41, p=0.24)$ but not for the highest dose $(0.5 \mathrm{mg} / \mathrm{kg}$; all $p$ values $>0.46)$. Monkeys with higher $\mathrm{D}_{2}$-like receptor availability exhibited greater responses to low/threshold doses than their counterparts with low $\mathrm{D}_{2}$-like receptor availability, suggesting that they were more sensitive to agonist-induced increases in EBR. This effect was pharmacologically specific in that changes in EBR caused by administration of the $\mathrm{D}_{1}$-like receptor agonist (A77636; 0.005, 0.05, and $0.5 \mathrm{mg} / \mathrm{kg}$ ) were neither correlated with individual differences in $\mathrm{D}_{1}$-like (Fig. $4 F$ ) or $\mathrm{D}_{2}$-like, receptor availability (all $p$ values $>0.31$ ).

To further establish the connection of EBR among the behavioral phenotypes that are related to dopamine $\mathrm{D}_{2}$-like receptor availability, we explored the relationship between EBR and positive-feedback sensitivity during reversal. EBR was related to the sensitivity of monkeys to positive feedback $(r=0.68 ; p=0.04)$, and when EBR and positive-feedback sensitivity were regressed against $\mathrm{D}_{2}$-like receptor availability, the two phenotypes accounted for overlapping portions of variance in the PET measure $\left(R_{\text {spontaneous EBR }}^{2}=0.50 ; R_{\text {spontaneous EBR and positive-feedback sensitivity }}^{2}=\right.$ 0.59 ), indicating that the variance they share individually with $D_{2}$ like receptor availability is also shared with one another.

\section{$D_{2}$-like receptor availability is related to receptor density, but not to dopamine content, in striatal tissue}

Both receptor density and levels of dopamine that compete for occupancy of $\mathrm{D}_{2}$-like receptors with the radiotracer can influence receptor availability measured with PET. To dissect contributions of these factors, brain tissue from striatal subregions of each subject was collected. Neither tissue content of dopamine nor a measure of dopamine utilization (ratio of homovanillic acid levels/dopamine levels) was correlated with $\mathrm{D}_{2}$-like receptor availability (all $p$ values $>0.19$ ) or EBR (all $p$ values $>0.25$ ).

Conversely, we found that receptor density for the lowaffinity $\mathrm{D}_{2}$-like receptor ligand $\left[{ }^{3} \mathrm{H}\right]$ raclopride $\left(B_{\max }\right)$ in homogenates extracted from putamen tissue was positively related to the $\mathrm{D}_{2}$-like receptor availability in the putamen $(r=0.72 ; p=0.04$; Fig. $5 A)$ and to $\operatorname{EBR}(r=0.72 ; p=0.04$; Fig. $5 B)$. Furthermore, the density of $\left[{ }^{3} \mathrm{H}\right]$ raclopride binding sites in the putamen was positively related to $\mathrm{D}_{2}$-like receptor availability in the caudate nucleus $(r=0.60 ; p=0.06)$ and ventral striatum $(r=0.55 ; p=$ $0.10)$, although these relationships did reach conventional levels of statistical significance. Differently, the equilibrium dissociation constant $\left(K_{\mathrm{D}}\right)$, a measure of affinity of the ligand for the receptor, did not relate to $\mathrm{D}_{2}$-like receptor availability in the putamen $(r=0.38 ; p=0.35)$ or EBR $(r=0.51 ; p=0.20)$. Furthermore, the density of $\left[{ }^{3} \mathrm{H}\right]$ raclopride binding sites in the putamen was positively related to $\mathrm{D}_{2}$ agonist-induced increases in EBR 

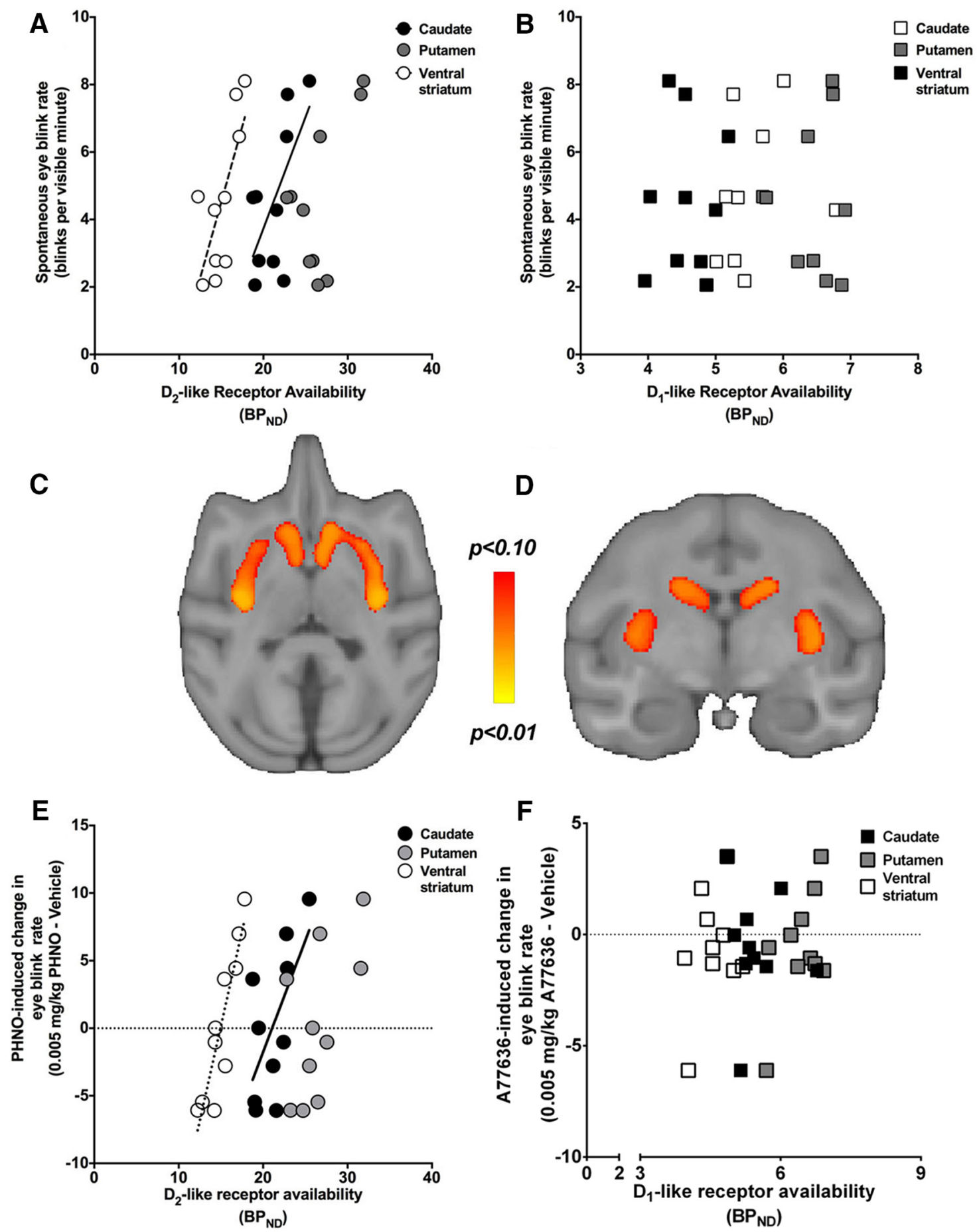

Figure 4. EBR is related to $D_{2}$-like receptor availability. $A, P E T D_{2}$-like receptor availability measurements in the ventral striatum (white circles) and caudate nucleus (black circles), but not putamen (gray circles), were positively related to EBR. $\boldsymbol{B}, \mathrm{D}_{1}$-like receptor availability in the ventral striatum (white squares), caudate nucleus (black squares), or putamen (gray squares) was not significantly related to EBR. $C, D, A$ voxelwise, linear regression of EBR on $\mathrm{PET}_{2}$-like receptor availability revealed statistically significant correlations (bright colors) throughout the striatum. Figures are presented as threshold-free cluster enhancement (TFCE) statistical maps ( $p$ values) overlaid on the study-specific vervet monkey MRI template in the transverse $(\boldsymbol{C})$ and coronal $(\boldsymbol{D})$ planes and thresholded at $p<0.1$, corrected for the entire striatal search volume. $E_{1} D_{2}$-like receptor availability in the ventral striatum (white circles) and caudate nucleus (black circles) was significantly correlated with the maximal $\mathrm{D}_{2}$-agonist induced change in EBR. $\boldsymbol{F}_{1} \mathrm{D}_{1}$-like receptor availability in the caudate nucleus (black squares), putamen (gray squares), or ventral striatum (white squares) was not significantly related to the maximal $D_{1}$ agonist-induced change in EBR (produced with $A 77636 ; 0.005 \mathrm{mg} / \mathrm{kg}$ ).

$(r=0.70 ; p=0.05 ;$ Fig. $5 C)$. We then compared the density of $\left[{ }^{3} \mathrm{H}\right]$ raclopride binding sites in the putamen with positivefeedback sensitivity in the reversal phase and found that there was a positive, albeit nonsignificant, relationship $(r=0.46 ; p=0.29$; Fig. $5 D$ ).
EBR explains the relationship between tissue-based and imaging-based measures of $D_{2}$-like receptors

Given the multi-tiered relationships between ex vivo $\mathrm{D}_{2}$-like receptor density, EBR, PET-based measures of $\mathrm{D}_{2}$-like receptor availability, sensitivity to positive feedback, and inhibitory con- 

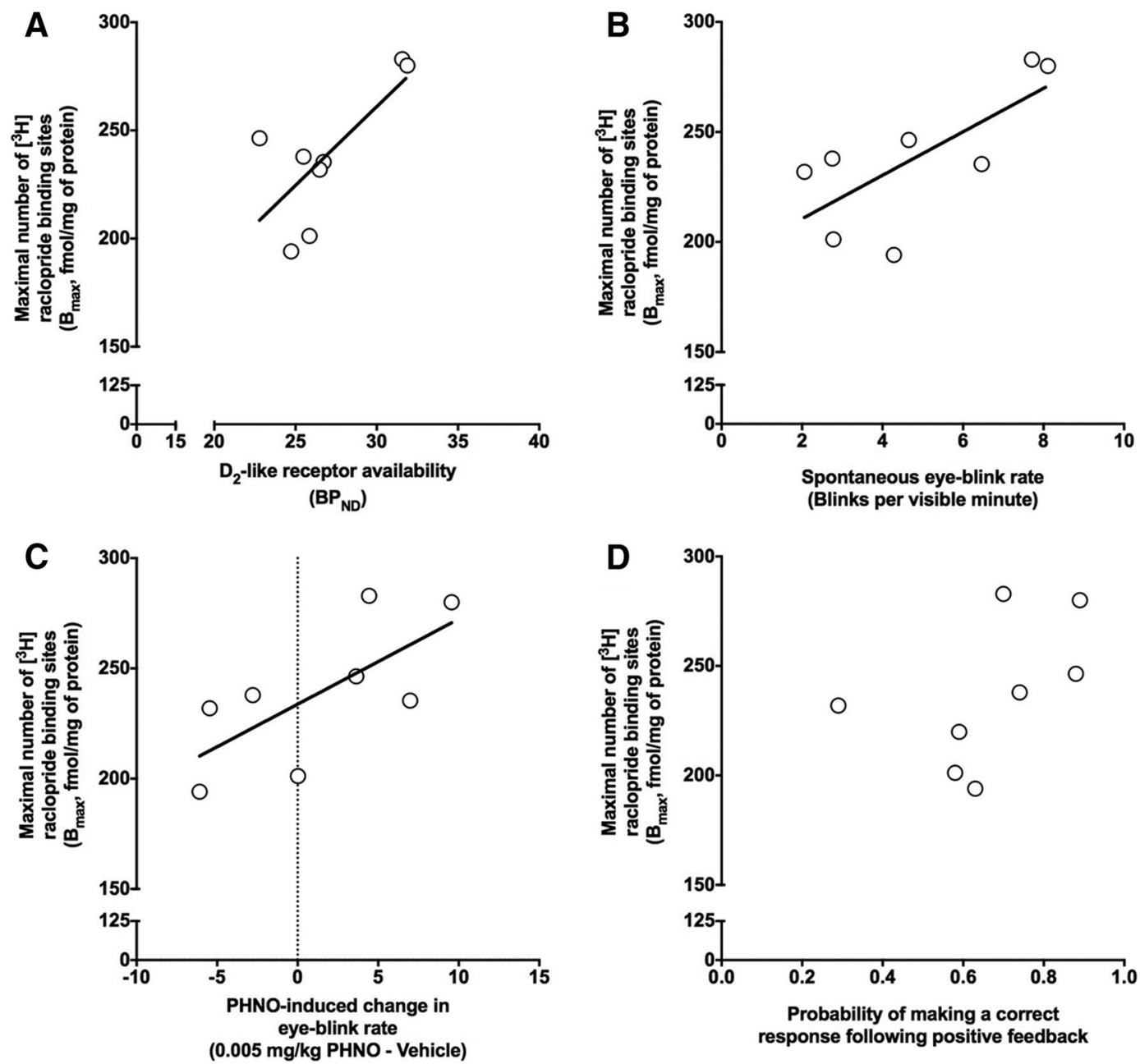

Figure 5. Ex vivo striatal $D_{2}$-like receptor density from putamen tissue homogenates is related to PET $D_{2}$-like receptor availability measurements in the putamen and EBR. $A, D_{2}$-like receptor availability in the putamen is positively related to ex vivo $\mathrm{D}_{2}$-like receptor density $\left(B_{\max }\right)$ from putamen tissue homogenates assessed using the $\left[{ }^{3} \mathrm{H}\right]$ raclopride radioligand binding assay. $\boldsymbol{B}$, EBR was positively related to ex vivo putamen $D_{2}$-like receptor density $\left(B_{\max }\right) \cdot \boldsymbol{C}$, The maximal $D_{2}$ agonist-induced change in EBR was positively related to putamen $D_{2}$-like receptor density $\left(B_{\max }\right) . \boldsymbol{D}$, The probability of making a correct response after positive feedback was positively related to putamen $\mathrm{D}_{2}$-like receptor density $\left(B_{\text {max }}\right)$, but this relationship was not statistically significant.

trol in a reversal-learning task, we hypothesized-on the basis of a model of progressively increasing biobehavioral complexity, from tissue binding, to behaviors of variable cognitive demands, to broad neocortical phenotypes - that the statistical association between ex vivo $\mathrm{D}_{2}$-like receptor density and positive-feedback sensitivity might arise via indirect effects on EBR and PET $\mathrm{D}_{2}$-like receptor availability measurements. To test this, a path analysis was conducted; we included a single exogenous variable (ex vivo $\mathrm{D}_{2}$-like receptor density) and four endogenous variables (EBR, $\mathrm{D}_{2}$-like receptor availability, positive-feedback sensitivity, and performance [trials to criterion] during reversal). The saturated model (Fig. 6A), in which all direct and indirect effects are considered (including the direct effect of positive-feedback sensitivity on reversal phase performance), explained $97 \%$ of the variance in behavioral sensitivity to positive feedback in the reversal task. When the saturated model was reduced to a model in which ex vivo $\mathrm{D}_{2}$-like receptor density has only an indirect effect on positive-feedback sensitivity (Fig. $6 B$ ), the path model explained $89 \%$ of the variance in positive-feedback sensitivity. Because the latter model was, according to likelihood ratio testing, as informative as the fully saturated model $\left(\chi^{2}=5.17 ; p=0.88\right)$, it was selected on the basis of parsimony. Furthermore, the re- duced model positioned EBR between ex vivo $\mathrm{D}_{2}$-like receptor density and PET $\mathrm{D}_{2}$-like receptor availability measurements, suggesting that EBR measures statistically account for the relationship between ex vivo $\mathrm{D}_{2}$-like receptor density and PET $\mathrm{D}_{2}$-like receptor availability measurements.

\section{Discussion}

Here, we describe a set of experiments designed to identify the biological mechanisms indirectly assessed by PET and radiotracers that label $\mathrm{D}_{2}$-like receptors. The data gathered, using a withinsubjects design, provide direct evidence that variation in PET $\mathrm{D}_{2}$-like receptor availability measurements reveal underlying differences in the density of functional and behaviorally relevant $\mathrm{D}_{2}$-like receptors, providing a framework for the interpretation of PET-based measures of $\mathrm{D}_{2}$ receptor availability. Moreover, we demonstrate that EBR is an easy-to-quantify, minimally invasive phenotype that accounts for significant proportions of naturally occurring variation in $\mathrm{D}_{2}$-like receptor availability in the nonhuman primate. As such, we provide preliminary evidence of its utility as a behavioral biomarker of striatal dopamine $\mathrm{D}_{2}$-like receptors and, ultimately, its associated phenotypes, including behavioral sensitivity to positive feedback. 

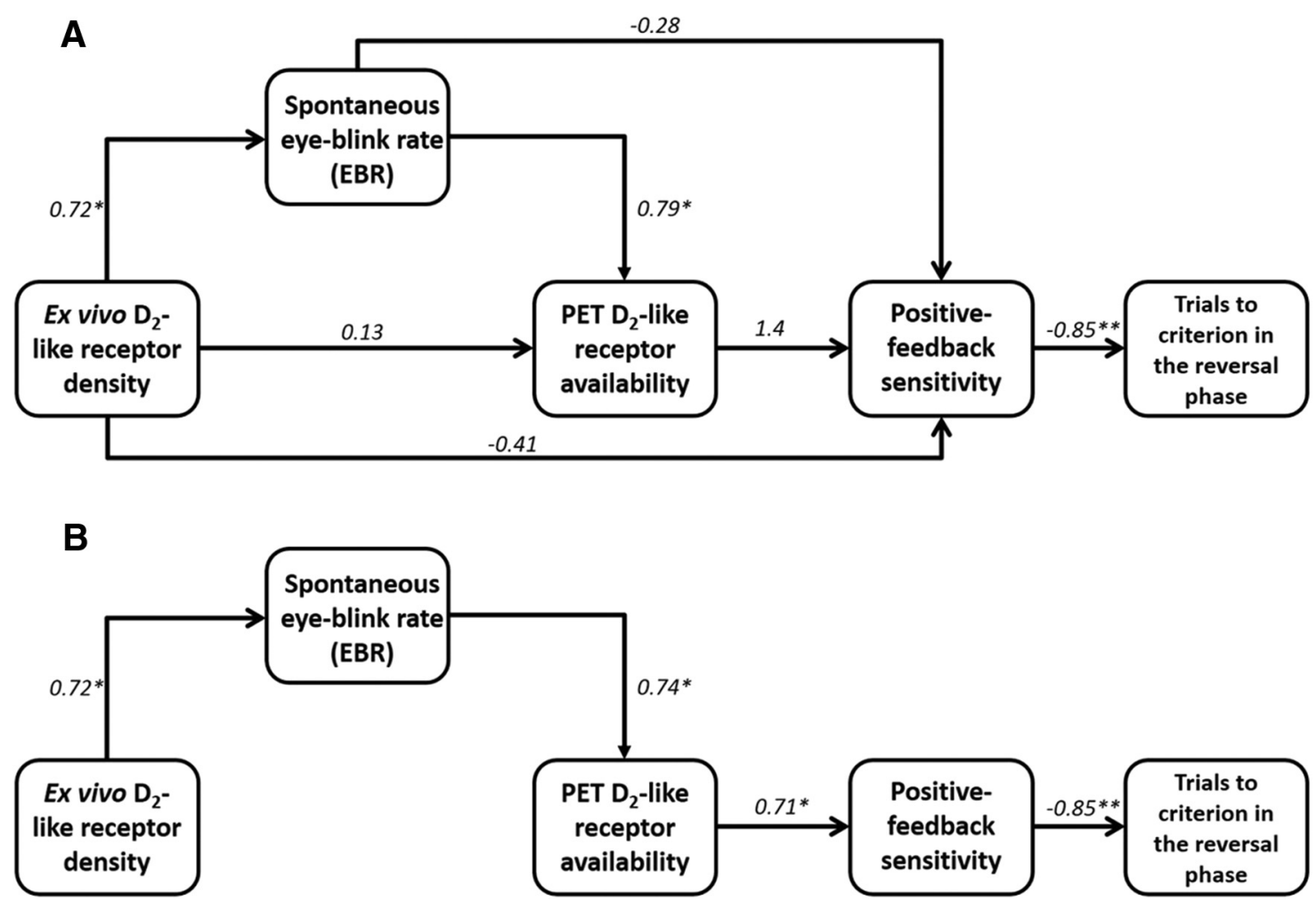

Figure 6. Statistical path analysis indicates that EBR is a behavioral biomarker of striatal $D_{2}$-like receptor density. $A, A$ path analysis was conducted to determine the relationship between ex vivo $\mathrm{D}_{2}$-like receptor density, EBR, PET D ${ }_{2}$-like receptor availability, and positive-feedback sensitivity. The saturated model, in which all direct and indirect effects were included and the path weighting expressed as standardized regression coefficients, explained $97 \%$ of the variance in positive-feedback sensitivity. ${ }^{*} p<0.05$, significant regression coefficients; ${ }^{* *} p<0.01$, a significant regression coefficient. $\boldsymbol{B}$, When the saturated model was reduced by removing nonsignificant paths and reevaluating the model after removal of each three paths, the theoretical model explained $89 \%$ of the variance in positive-feedback sensitivity, a contribution that did not differ significantly from that of the saturated model. In the reduced, theoretical model, all regression coefficients were statistically significant $\left({ }^{*} p<0.05 ;{ }^{* *} p<0.01\right.$ ) and revealed a model in which ex vivo $\mathrm{D}_{2}$-like receptor density influences positive-feedback sensitivity indirectly through EBR and EBR influences positivefeedback sensitivity indirectly through PET $D_{2}$-like receptor availability.

We extend our previous findings that individual differences in $\mathrm{D}_{2}$-like, but not $\mathrm{D}_{1}$-like, receptor availability covary with reversal-learning performance, adding to the growing evidence that relatively low $\mathrm{D}_{2}$-like receptor function is associated with performance in this test of reinforcement learning and inhibitory control (Groman et al., 2011, 2012). Pharmacological blockade and genetic deletion of the $\mathrm{D}_{2}$-like receptor impairs the ability of animals to reverse stimulus-response contingencies (Kruzich et al., 2006; Lee et al., 2007), while leaving the acquisition of stimulus response unaffected (Lee et al., 2007). Similarly, poor inhibitory control is exhibited by humans that carry the A1 + DRD2-ANKK1 gene variant (Jocham et al., 2009), which is associated with lower striatal $\mathrm{D}_{2}$-like receptor availability than the parallel variant (Jönsson et al., 1999), suggesting that the relationship between $\mathrm{D}_{2}$-like receptor and inhibitory control is evolutionarily conserved. Furthermore, we report that the relationship between $\mathrm{D}_{2}$-like receptor availability and performance on a reversal-learning task, which measures reinforcement learning and inhibitory control, is mediated by positive-feedback sensitivity, which may, itself, result from deficient dopamine-mediated positive prediction error signals to update stimulus-reward associations in subjects with relatively low dopamine $\mathrm{D}_{2}$-like receptor availability.

Notably, the relationship between receptor availability and reversal-learning performance was strongest in the ventral striatum, whereas a previous study of a separate group of monkeys showed that the relationship was strongest for the dorsal striatum (Groman et al., 2011). In both cohorts, the relationships were noted in all striatal regions, with data from different sections of the striatum crossing the statistical threshold for significance. Although the level of training may be relevant here [the current sample experienced less training, and prolonged training shifts behaviors to rely on more dorsal striatal mechanisms (Yin et al., 2004)], it seems more likely that the observed relationship between dopamine $\mathrm{D}_{2}$-like receptor availability and reversallearning performance generally holds for both dorsal and ventral parts of the striatum. Moreover, the direction of the relationship between $\mathrm{D}_{2}$-like receptor availability and inhibitory control is similar in nature to previous observations in mice (Laughlin et al., 2011) and rats (Dalley et al., 2007). The in vitro measurements reported here were performed on tissue extracted from the putamen, whereas the behavioral and neuroimaging relationships were strongest in the ventral striatum. Although this is a limitation, there were statistical trends for positive relationships between the putamen $\mathrm{D}_{2}$-like receptor density, measured in vitro, and $\mathrm{D}_{2}$-like receptor availability, measured in vivo, for all three striatal subregions, suggesting that $\mathrm{D}_{2}$-like receptor density across subregions is influenced by common factors, leading to a strong intercorrelation of the measures.

Substance-use disorders are conditions in which individuals lose voluntary control over drug seeking and taking, exhibiting compromised ability to exert inhibitory control over these actions despite deleterious outcomes associated with them. Low $\mathrm{D}_{2}$-like type availability has been detected in persons with substance-use disorders and in animal models of addiction (Volkow et al., 1993, 2001; Nader et al., 2006; Lee et al., 2009; Groman et al., 2012); in the past, these observations have been 
hypothesized to reflect differences in the densities of $\mathrm{D}_{2}$-like receptors. Relatively low $\mathrm{D}_{2}$-like receptor availability is associated with risk for substance use (Nader et al., 2006; Dalley et al., 2007) and behavioral risk factors for addiction (Zald et al., 2008; Lee et al., 2009; Buckholtz et al., 2010). For these reasons, the $\mathrm{D}_{2}$-like receptor system is hypothesized to influence both the liability for and progression of addiction (Groman and Jentsch, 2012; Jentsch and Pennington, 2014; Jentsch et al., 2014).

Nevertheless, the larger biological context through which individual differences in $\mathrm{D}_{2}$-like receptor density and function influence inhibitory control is not understood. Striatal $\mathrm{D}_{2}$-like receptor availability is positively related to glucose metabolism, an index of local brain function, in the orbitofrontal cortex of stimulant-dependent research participants (Volkow et al., 1993, 2001), a region implicated repeatedly in inhibitory control and addiction (London et al., 2000; Izquierdo and Murray, 2004; but see (Rudebeck et al., 2013). The mechanistic relationship between $\mathrm{D}_{2}$ receptors and orbitofrontal cortex metabolism is further supported by the observation that deficits in glucose metabolism in this brain region have also been observed in human carriers of the DRD2-ANKK1 Taq A1 + allele (Noble et al., 1997). Therefore, striatal $D_{2}$-like receptors may be related to the molecular and/or functional integrity of the orbitofrontal cortex through striato-pallido-thalamic loops that integrate frontocortical regions with the striatum (Haber, 2003). Additionally, a subset of striatal $\mathrm{D}_{2}$-like receptors control presynaptic release of glutamate from corticostriatal terminals (Cepeda et al., 2001); these receptors control long-term depression of cortical inputs to the striatum (Bamford et al., 2004). An impairment of dopamine-mediated long-term depression of inputs from the orbitofrontal cortex attributable to low $\mathrm{D}_{2}$-like receptor availability could bias an organism to develop strong, habitual behaviors (Bock et al., 2013) that are inflexible and/or resistant to top-down inhibitory control influences. These studies provide multiple mechanisms by which $\mathrm{D}_{2}$-like receptors in the striatum could contribute to inhibitory control over inappropriate behaviors.

Although several studies demonstrate correlations between striatal $\mathrm{D}_{2}$-like receptors and addiction-related phenotypes, it is possible that $\mathrm{D}_{2}$-like receptors in other brain regions contribute to the behavioral endpoints. PET imaging studies have predominantly focused on the striatum, a region with the greatest abundance of $\mathrm{D}_{2}$-like receptors, but recent studies have investigated the relationships between midbrain $\mathrm{D}_{2}$-like receptor availability (presumably a measure of autoreceptors) and addiction-risk phenotypes in humans (Zald et al., 2008) and mice (Laughlin et al., 2011). Alternatively, pharmacological manipulations of dopamine $\mathrm{D}_{2}$-like receptor signaling in frontal cortical regions can affect control over habitual responding (Calaminus and Hauber, 2008), and $D_{2}$ receptor modulation of frontal cortical neurons and function is reduced in animals exposed to drugs of abuse (Kroener and Lavin, 2010). If binding potential measured in the striatum were correlated with binding potentials in midbrain and frontal cortex, striatal measures of $\mathrm{D}_{2}$-like receptors may simply be a biomarker of the underlying mechanistic relationship that depends on these receptors in another brain region. Thus, $\mathrm{D}_{2}$-like receptors in multiple brain regions within the mesocorticostriatal circuit may exert mechanistically synergistic, or independent, influences on inhibitory control and addiction. However, pharmacological depletion of dopamine and dopaminergic manipulations confined to the striatum impairs inhibitory control (O'Neill and Brown, 2007; Haluk and Floresco, 2009). This observation may be a consequence of disrupting the interaction between striatal dopamine systems and orbitofrontal serotonin that underlie inhibitory control (Groman et al., 2013b).

Of practical importance and value, the results of the current study suggest that EBR may be a biomarker of striatal $\mathrm{D}_{2}$-like receptors, relating to both in vitro and in vivo $\mathrm{D}_{2}$-like receptor measurements and $\mathrm{D}_{2}$-dependent behaviors. Because EBR can be easily and non-invasively quantified in sensitive populations (e.g., children and individuals with psychiatric conditions) across multiple time points and locations, it may offer potential advantages over PET measures that make it useful in developmental studies. Developmental regulation of dopamine $\mathrm{D}_{2}$ receptor signaling in frontostriatal circuits occurs during maturation (Ernst et al., 2009), and adolescence is a period that is highly relevant to substance use and abuse (Hawkins et al., 1992) and to the development of other dopamine-related disorders, such as schizophrenia (Lewis, 1997). Based on the preliminary evidence presented here, we suggest that EBR may represent an important biobehavioral phenotype for testing hypotheses about the role for developmental regulation of $\mathrm{D}_{2}$-like signaling in disorders of childhood and adolescence. However, additional studies are needed to determine the extent to which pharmacological and/or viral manipulations of $\mathrm{D}_{2}$-like receptors affect $\mathrm{EBR}$, as well as the neural circuitry that underlies EBR. Although the current study did not detect a significant relationship between $D_{1}$-like receptor availability and $\mathrm{D}_{1}$-agonist induced changes in EBR, this relationship may be detectable at higher doses of the $D_{1}$ agonist that produce greater enhancements in EBR.

Together, these results provide a multidimensional analysis, spanning a broad range of phenotypic complexity, that individual differences in $\mathrm{D}_{2}$-like PET measurements that relate to positive-feedback sensitivity and reversal-learning performance reflect the densities of functional and behaviorally relevant $\mathrm{D}_{2}$ like receptors and can be predicted by measurement of EBR. Thus, they highlight the power of within-subject, multimodal phenotypic assessments in animal models for understanding the biological bases of human endophenotypes and, by consequence, the identification of biochemical targets for the treatment of psychiatric disorders.

\section{References}

Bamford NS, Robinson S, Palmiter RD, Joyce JA, Moore C, Meshul CK (2004) Dopamine modulates release from corticostriatal terminals. J Neurosci 24:9541-9552. CrossRef Medline

Baron RM, Kenny DA (1986) The moderator-mediator variable distinction in social psychological research: conceptual, strategic, and statistical considerations. J Pers Soc Psychol 51:1173-1182. CrossRef Medline

Bock R, Shin JH, Kaplan AR, Dobi A, Markey E, Kramer PF, Gremel CM, Christensen CH, Adrover MF, Alvarez VA (2013) Strengthening the accumbal indirect pathway promotes resilience to compulsive cocaine use. Nat Neurosci 16:632-638. CrossRef Medline

Buckholtz JW, Treadway MT, Cowan RL, Woodward ND, Benning SD, Li R, Ansari MS, Baldwin RM, Schwartzman AN, Shelby ES, Smith CE, Cole D, Kessler RM, Zald DH (2010) Mesolimbic dopamine reward system hypersensitivity in individuals with psychopathic traits. Nat Neurosci 13: 419-421. CrossRef Medline

Calaminus C, Hauber W (2008) Guidance of instrumental behavior under reversal conditions requires dopamine $\mathrm{D} 1$ and $\mathrm{D} 2$ receptor activation in the orbitofrontal cortex. Neuroscience 154:1195-1204. CrossRef Medline

Cepeda C, Hurst RS, Altemus KL, Flores-Hernández J, Calvert CR, Jokel ES, Grandy DK, Low MJ, Rubinstein M, Ariano MA, Levine MS (2001) Facilitated glutamatergic transmission in the striatum of D2 dopamine receptor-deficient mice. J Neurophysiol 85:659-670. Medline

Dalley JW, Fryer TD, Brichard L, Robinson ES, Theobald DE, Lääne K, Peña Y, Murphy ER, Shah Y, Probst K, Abakumova I, Aigbirhio FI, Richards HK, Hong Y, Baron JC, Everitt BJ, Robbins TW (2007) Nucleus accum- 
bens D2/3 receptors predict trait impulsivity and cocaine reinforcement. Science 315:1267-1270. CrossRef Medline

Edwards JR, Lambert LS (2007) Methods for integrating moderation and mediation: a general analytical framework using moderated path analysis. Psychol Methods 12:1-22. CrossRef Medline

Elsworth JD, Lawrence MS, Roth RH, Taylor JR, Mailman RB, Nichols DE, Lewis MH, Redmond DE Jr (1991) D1 and D2 dopamine receptors independently regulate spontaneous blink rate in the vervet monkey. J Pharmacol Exp Ther 259:595-600. Medline

Ernst M, Romeo RD, Andersen SL (2009) Neurobiology of the development of motivated behaviors in adolescence: a window into a neural systems model. Pharmacol Biochem Behav 93:199-211. CrossRef Medline

Fears SC, Melega WP, Service SK, Lee C, Chen K, Tu Z, Jorgensen MJ, Fairbanks LA, Cantor RM, Freimer NB, Woods RP (2009) Identifying heritable brain phenotypes in an extended pedigree of vervet monkeys. J Neurosci 29:2867-2875. CrossRef Medline

Frank MJ, Seeberger LC, O'Reilly RC (2004) By carrot or by stick: cognitive reinforcement learning in parkinsonism. Science 306:1940-1943. CrossRef Medline

Frank MJ, Moustafa AA, Haughey HM, Curran T, Hutchison KE (2007) Genetic triple dissociation reveals multiple roles for dopamine in reinforcement learning. Proc Natl Acad Sci U S A 104:16311-16316. CrossRef Medline

Ghahremani DG, Lee B, Robertson CL, Tabibnia G, Morgan AT, De Shetler N, Brown AK, Monterosso JR, Aron AR, Mandelkern MA, Poldrack RA, London ED (2012) Striatal dopamine $\mathrm{D}_{2} / \mathrm{D}_{3}$ receptors mediate response inhibition and related activity in frontostriatal neural circuitry in humans. J Neurosci 32:7316-7324. CrossRef Medline

Groman SM, Jentsch JD (2012) Cognitive control and the dopamine D(2)like receptor: a dimensional understanding of addiction. Depress Anxiety 29:295-306. CrossRef Medline

Groman SM, Lee B, London ED, Mandelkern MA, James AS, Feiler K, Rivera R, Dahlbom M, Sossi V, Vandervoort E, Jentsch JD (2011) Dorsal striatal D2-like receptor availability covaries with sensitivity to positive reinforcement during discrimination learning. J Neurosci 31:7291-7299. CrossRef Medline

Groman SM, Lee B, Seu E, James AS, Feiler K, Mandelkern MA, London ED, Jentsch JD (2012) Dysregulation of d2-mediated dopamine transmission in monkeys after chronic escalating methamphetamine exposure. J Neurosci 32:5843-5852. CrossRef Medline

Groman SM, Morales AM, Lee B, London ED, Jentsch JD (2013a) Methamphetamine-induced increases in putamen gray matter associate with inhibitory control. Psychopharmacology (Berl) 229:527-538. CrossRef Medline

Groman SM, James AS, Seu E, Crawford MA, Harpster SN, Jentsch JD (2013b) Monoamine levels within the orbitofrontal cortex and putamen interact to predict reversal learning performance. Biol Psychiatry 73:756762. CrossRef Medline

Guo N, Guo W, Kralikova M, Jiang M, Schieren I, Narendran R, Slifstein M, Abi-Dargham A, Laruelle M, Javitch JA, Rayport S (2010) Impact of D2 receptor internalization on binding affinity of neuroimaging radiotracers. Neuropsychopharmacology 35:806-817. CrossRef Medline

Haber SN (2003) The primate basal ganglia: parallel and integrative networks. J Chem Neuroanat 26:317-330. CrossRef Medline

Haluk DM, Floresco SB (2009) Ventral striatal dopamine modulation of different forms of behavioral flexibility. Neuropsychopharmacology 34 : 2041-2052. CrossRef Medline

Hawkins JD, Catalano RF, Miller JY (1992) Risk and protective factors for alcohol and other drug problems in adolescence and early adulthood: implications for substance abuse prevention. Psychol Bull 112:64-105. CrossRef Medline

Ito H, Kodaka F, Takahashi H, Takano H, Arakawa R, Shimada H, Suhara T (2011) Relation between presynaptic and postsynaptic dopaminergic functions measured by positron emission tomography: implication of dopaminergic tone. J Neurosci 31:7886-7890. CrossRef Medline

Izquierdo A, Jentsch JD (2012) Reversal learning as a measure of impulsive and compulsive behavior in addictions. Psychopharmacology (Berl.) 219: 607-620. CrossRef Medline

Izquierdo A, Murray EA (2004) Combined unilateral lesions of the amygdala and orbital prefrontal cortex impair affective processing in rhesus monkeys. J Neurophysiol 91:2023-2039. CrossRef Medline

Jentsch JD, Pennington ZT (2014) Reward, interrupted: Inhibitory control and its relevance to addictions. Neuropharmacology 76:479-486. CrossRef Medline

Jentsch JD, Tran A, Le D, Youngren KD, Roth RH (1997) Subchronic phencyclidine administration reduces mesoprefrontal dopamine utilization and impairs prefrontal cortical-dependent cognition in the rat. Neuropsychopharmacology 17:92-99. CrossRef Medline

Jentsch JD, Ashenhurst JR, Cervantes MC, Groman SM, James AS, Pennington ZT (2014) Dissecting impulsivity and its relationships to drug addictions. Ann N Y Acad Sci. Advance online publication. Retrieved September 23, 2014. doi:10.1111/nyas.12388. CrossRef Medline

Jocham G, Klein TA, Neumann J, von Cramon DY, Reuter M, Ullsperger M (2009) Dopamine DRD2 polymorphism alters reversal learning and associated neural activity. J Neurosci 29:3695-3704. CrossRef Medline

Jönsson EG, Nöthen MM, Grünhage F, Farde L, Nakashima Y, Propping P, Sedvall GC (1999) Polymorphisms in the dopamine D2 receptor gene and their relationships to striatal dopamine receptor density of healthy volunteers. Mol Psychiatry 4:290-296. CrossRef Medline

Kleven MS, Koek W (1996) Differential effects of direct and indirect dopamine agonists on eye blink rate in cynomolgus monkeys. J Pharmacol Exp Ther 279:1211-1219. Medline

Kroener S, Lavin A (2010) Altered dopamine modulation of inhibition in the prefrontal cortex of cocaine-sensitized rats. Neuropsychopharmacology 35:2292-2304. CrossRef Medline

Kruzich PJ, Mitchell SH, Younkin A, Grandy DK (2006) Dopamine D2 receptors mediate reversal learning in male C57BL/6J mice. Cogn Affect Behav Neurosci 6:86-90. CrossRef Medline

Laughlin RE, Grant TL, Williams RW, Jentsch JD (2011) Genetic dissection of behavioral flexibility: reversal learning in mice. Biol Psychiatry 69: 1109-1116. CrossRef Medline

Lee B, Groman S, London ED, Jentsch JD (2007) Dopamine D2/D3 receptors play a specific role in the reversal of a learned visual discrimination in monkeys. Neuropsychopharmacology 32:2125-2134. CrossRef Medline

Lee B, London ED, Poldrack RA, Farahi J, Nacca A, Monterosso JR, Mumford JA, Bokarius AV, Dahlbom M, Mukherjee J, Bilder RM, Brody AL, Mandelkern MA (2009) Striatal dopamine D2/D3 receptor availability is reduced in methamphetamine dependence and is linked to impulsivity. J Neurosci 29:14734-14740. CrossRef Medline

Levant B (2007) Characterization of dopamine receptors. In: Current protocols in pharmacology. Hoboken, NJ: Wiley.

Lewis DA (1997) Development of the prefrontal cortex during adolescence: insights into vulnerable neural circuits in schizophrenia. Neuropsychopharmacology 16:385-398. CrossRef Medline

London ED, Ernst M, Grant S, Bonson K, Weinstein A (2000) Orbitofrontal cortex and human drug abuse: functional imaging. Cereb Cortex 10:334342. CrossRef Medline

Lowry OH, Rosebrough NJ, Farr AL, Randall RJ (1951) Protein measurement with the Folin phenol reagent. J Biol Chem 193:265-275. Medline

Merritt KE, Bachtell RK (2013) Initial d2 dopamine receptor sensitivity predicts cocaine sensitivity and reward in rats. PLoS One 8:e78258. CrossRef Medline

MukherjeeJ, Yang ZY, Das MK, Brown T (1995) Fluorinated benzamide neuroleptics-III. Development of (S)-N-[(1-allyl-2-pyrrolidinyl)methyl]-5(3-[18F]fluoropropyl)-2, 3-dimethoxybenzamide as an improved dopamine D-2 receptor tracer. Nucl Med Biol 22:283-296. CrossRef Medline

Nader MA, Morgan D, Gage HD, Nader SH, Calhoun TL, Buchheimer N, Ehrenkaufer R, Mach RH (2006) PET imaging of dopamine D2 receptors during chronic cocaine self-administration in monkeys. Nat Neurosci 9:1050-1056. CrossRef Medline

Noble EP, Gottschalk LA, Fallon JH, Ritchie TL, Wu JC (1997) D2 dopamine receptor polymorphism and brain regional glucose metabolism. Am J Med Genet 74:162-166. CrossRef Medline

O’Neill M, Brown VJ (2007) The effect of striatal dopamine depletion and the adenosine A2A antagonist KW-6002 on reversal learning in rats. Neurobiol Learn Mem 88:75-81. CrossRef Medline

Rudebeck PH, Saunders RC, Prescott AT, Chau LS, Murray EA (2013) Pre- 
frontal mechanisms of behavioral flexibility, emotion regulation and value updating. Nat Neurosci 16:1140-1145. CrossRef Medline

Schmidt DE, Votaw JR, Kessler RM, de Paulis T (1994) Aromatic and amine substituent effects on the apparent lipophilicities of $\mathrm{N}$-[(2-pyrrolidinyl)methyl]substituted benzamides. J Pharm Sci 83:305-315. CrossRef Medline

Szumlinski KK, Allan M, Talangbayan H, Tracey A, Szechtman H (1997) Locomotor sensitization to quinpirole: environment-modulated increase in efficacy and context-dependent increase in potency. Psychopharmacology (Berl) 134:193-200. CrossRef Medline

Taylor JR, Elsworth JD, Lawrence MS, Sladek JR Jr, Roth RH, Redmond DE, Jr (1999) Spontaneous blink rates correlate with dopamine levels in the caudate nucleus of MPTP-treated monkeys. Exp Neurol 158:214-220. CrossRef Medline

Vandervoort E, Sossi V (2008) An analytical scatter correction for singlesmode transmission data in PET. IEEE Trans Med Imaging 27:402-412. CrossRef Medline
Volkow ND, Fowler JS, Wang GJ, Hitzemann R, Logan J, Schlyer DJ, Dewey SL, Wolf AP (1993) Decreased dopamine D2 receptor availability is associated with reduced frontal metabolism in cocaine abusers. Synapse 14:169-177. CrossRef Medline

Volkow ND, Chang L, Wang GJ, Fowler JS, Ding YS, Sedler M, Logan J, Franceschi D, Gatley J, Hitzemann R, Gifford A, Wong C, Pappas N (2001) Low level of brain dopamine D2 receptors in methamphetamine abusers: association with metabolism in the orbitofrontal cortex. Am J Psychiatry 158:2015-2021. CrossRef Medline

Yin HH, Knowlton BJ, Balleine BW (2004) Lesions of dorsolateral striatum preserve outcome expectancy but disrupt habit formation in instrumental learning. Eur J Neurosci 19:181-189. CrossRef Medline

Zald DH, Cowan RL, Riccardi P, Baldwin RM, Ansari MS, Li R, Shelby ES, Smith CE, McHugo M, Kessler RM (2008) Midbrain dopamine receptor availability is inversely associated with novelty-seeking traits in humans. J Neurosci 28:14372-14378. CrossRef Medline 